\title{
Contrasting Ability of Steroidal (ICI 182 780) and Non-steroidal (EM-800) Antiestrogens to Inhibit Reproductive Organ Growth in Male and Female Mice
}

\author{
J. KOTANOVÁ, E. KÖHLEROVÁ, J. ŠKARDA \\ Institute of Animal Physiology and Genetics, Academy of Sciences, Prague, Czech Republic
}

Received June 24, 2005

Accepted November 10, 2005

\begin{abstract}
Kotanová J., E. Köhlerová, J. Škarda: Contrasting Ability of Steroidal (ICI 182 780) and Non-steroidal (EM-800) Antiestrogen to Inhibit Reproductive Organ Growth in Male and Female Mice. Acta Vet. Brno 2005, 74: 533-541.

The changes in mammary, uterine and seminal vesicle growth were intended to identify the in vivo activity of estrogen antagonists. Using the combinations of hormone agonist and antagonist, we tested and compared four model systems, the young intact and adult gonadectomized male and female mice. Steroidal antiestrogen ICI 182780 (ICI) always behaved as an antiestrogen: ICI alone or in combination with estradiol (E) or progesterone (Prog) decreased mammary and uterine growth in prepubertal and adult ovariectomized (OV-X) females and decreased mammary growth in prepubertal adult castrated males treated with E. In prepubertal males ICI alone or in combination with Prog or E also increased seminal vesicle weights. Nonsteroidal antiestrogen EM800 (EM) alone, on the other hand, had no effect on mammary and uterine growth in prepubertal females, and in adult OV-X females uterine growth was even stimulated by EM alone, and a combination of EM plus Prog stimulated not only uterine growth but also mammary growth ( the estrogenic effects). EM synergized with $\mathrm{E}$ in decreasing seminal vesicle weights in $\mathrm{E}$ treated prepubertal males. However, EM decreased E stimulated mammary growth in prepubertal and adult gonadectomized females and males and E stimulated uterine growth in prepubertal and adult OV-X females. EM increased Prog stimulated seminal vesicle weights in prepubertal males (the antiestrogenic effects).
\end{abstract}

Antiestrogen, growth, mammary gland, uterus, seminal vesicles, mice

Estrogens and progesterone regulate the development and maintenance of the female reproductive system. Despite the classical contention that estrogen is the female hormone, compelling evidence indicates a pivotal role of estrogen in the regulation of development and function of several systems in the male (Tena-Sempere et al. 2000). In the male, the physiological role of estrogens involves multiple actions, from masculinization of brain areas related to reproductive function and sexual behavior to regulation of testicular development and function, as well as direct effects on bone and the cardiovascular system (Nilss on et al. 1998; Sharpe 1998).

Many of the biological effect of estrogens are mediated by their binding to nuclear receptors. Nuclear hormone receptors represent an evolutionary conserved class of transcription factors being present from flies to mammals (B e a to et al. 1995). Upon binding the estrogenic compound, the transcriptionally inactive estrogen receptor (ER) undergoes conformational (activating ) changes that facilitate the interaction of receptor with specific palindromic DNA sequences (estrogen response elements) within the regulatory regions of target genes as liganded receptor dimers. However, all estrogenic compounds do not produce the same conformation of receptors, and the ability of ligand-bound receptors to regulate target gene transcription is determined by the cell- and tissue- specific expression of both different coactivator and corepressor proteins that impact the ER signalling pathway (Paige et al. 1999). Adding to this complexity there are two ER subtypes - ER $\alpha$ and ER $\beta$ (Kuiper et al. 1996). In man, the genes for the two ER are located on different chromosomes and have

Address for correspondence:

Doc. MVDr. Josef Škarda, DrSc.

Institute of Animal Physiology and Genetics

Academy of Sciences of the Czech Republic

Vídeňská 1083, 14220 Prague 4, Czech Republic
Phone: + 420267090505

Fax: + 420227090500

e-mail: skarda@iapg.cas.cz

http://www.vfu.cz/acta-vet/actavet.htm 
a different but overlapping distribution pattern in different cells (Enmark et al. 1997). In addition it has been shown that one estrogenic compound may be bound with different affinities to the various receptor variants (Kuiper et al. 1997) or may exhibit different agonist antagonist activities (Barkhem et al. 1998). Moreover, it must be assumed that heterologous (ER $\alpha+$ ER $\beta$ ) dimerization products may form following binding of the ligand (Cowley et al. 1997; Hoffman and Schuler 2000). Thus, depending on the expression of receptors in a target tissue, different responses may be induced by the same ligand.

Steroid receptor antagonists exhibiting a competitive binding to the ER have been developed and are presently in use for therapy in human medicine. In animals, however, apart from the application in laboratory animals there are data from experimental use in domestic animals (Jacobs et al. 1988; Janowski et al. 1996; All-Matubsi et al. 1998; Robertson et al. 2001).

Large number of natural and man-made chemicals with widely diverse chemical structure has the ability to mimic or inhibit the action of the endogenous estrogens by binding to and activating their receptors (Payne et al. 2000). This diversity makes it difficult to predict estrogenic or antiestrogenic activities on structural bases or radioimmunoassay. The detection and characterization of agents as estrogen agonist and antagonist necessitates the integrated use of in vivo and in vitro assays. However, the critical objective is to detect chemicals that may be active in vivo, thereby taking into account bioavailability and metabolism of a substance in animals.

Recently, we tested and compared four model screening systems for identification and

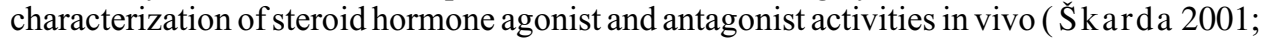
2002 abc, 2003; Hufriy et al 2003; Köhlerová and Škarda 2004). Screening systems are based on simultaneous evaluation of a combination of several endpoints (mammary, uterine, seminal vesicles and spleen growth responses) in prepubertal intact and adult ovariectomized (OV-X) females, and prepubertal intact and adult castrated males. Using four model systems is possible to determine different interactions of steroid hormone agonists or antagonist with endpoints in four different but standardized animals. It is also useful for the assessment of mixture effects of compounds with steroid hormone agonist and antagonist activities. This bioassay is both robust and versatile and it gives both higher sensitivity and higher specificity than one or two model systems (Šk arda $2002 \mathrm{abc}$ ). Period of hormone treatment is long enough to stimulate/inhibit mammary gland and uterine growth and mimic exposure to constant level of a compound for a significant phase of life much like that achieved in animals exposed to hormonally active xenobiotics. The changes in organ growth were determined following administration of a tested compound alone or in combination with hormones known to stimulate or inhibit organ growth.

Detection of estrogenicity of a compound is based on the stimulation of mammary and uterine growth and inhibition of seminal vesicle growth in the presence and absence of Prog. In general, the sensitivity of estrogenic assay on the mammary gland and seminal vesicles of prepubertal males is the same as that on female uterus but lower than that on female

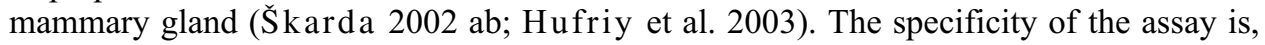
however, highest in male mammary gland as mammary growth in females is also stimulated with Prog alone and uterine weight is stimulated not only by E alone but also by testosterone and some antiestrogens (Köhlerová and Škarda 2004). Thus, uterine weight may be modulated through mechanisms that do not directly involve ER. The present data show that our four model systems has the ability to distinguish pure antiestrogens and selective estrogen receptor modulators (SERM). The identification of progestational compounds is mainly based on their ability to synergize with maximal dose of estrogens to produce a higher growth rate of mammary epithelial structures than that observed in mice treated with 
E alone. The formation of tubulo-alveolar buds and lateral branches is very sensitive parameter of progesterone action. Both antiprogestins and antiestrogens antagonize the effect of E plus Prog or NA-stimulated mammary and uterine growth and pure antiestrogens stimulated seminal vesicle growth in young intact males (Köhlerová and Škarda 2004; present results).

Detection of androgenic activity is based on the stimulation of seminal vesicle and uterine weights and on inhibition of E or E plus Prog stimulated mammary growth. Mammary growth may also be inhibited by glucocorticoids. To determine whether androgens or glucocorticoids cause inhibition of mammary growth, it should be realized that glucocorticoids in contrast to androgens have no ability to increase seminal vesicle weight in adult castrated males and that androgens in contrast to glucocorticoids have no ability to decrease spleen weights. The identification of antiandrogenic compounds consists of the following endpoints: inhibition of testosterone $(\mathrm{T})$ - stimulated seminal vesicle and uterine growth; compensation of $\mathrm{T}$ - inhibition of mammary growth. The sensitivity of androgen and antiandrogen assays is of course highest on seminal vesicles than on the uterus and mammary gland (Šk karda 2002c, 2003).

The aim of the present study was to characterize and compare the action of pure steroidal antiestrogen ICI 182780 (ICI) and non-steroidal antiestrogen EM-800 (EM) in four model systems. We show that ICI behaves as an antiestrogen in the mammary gland, uterus and seminal vesicles of animals treated with Prog or E. Antiestrogenic activity of EM was also demonstrated in the mammary gland and uterus of animals treated with $\mathrm{E}$, however, in adult $\mathrm{OV}-\mathrm{X}$ females treated with Prog EM acted as an estrogen agonist. In E treated young intact males EM synergized with E in decreasing seminal vesicle weights, however in Prog treated animals EM behaved as an antiestrogen.

\section{Materials and Methods}

\section{Materials}

Progesterone (Prog), 17ßestradiol (E), t-amylalcohol and methylsalicylate were purchased from Sigma-Aldrich (Prague, Czech Republic). 2,2,2-Tribromethanol (Fluka Chemie AG, Buchs Switzerland) was used for preparation of Advertin. Hematoxylin was bought from Merck (Darmstadt, Germany). Non-steroidal antiestrogen EM-800 (EM) was a gift from Oncology and Molecular Endocrinology Research Center, Laval Univ. Med. Center (Québec, Canada). Steroidal antiestrogen ICI was obtained both as a gift from Zeneca Pharmaceuticals, (Maclesfield, UK) and as goods purchased from Tocris Cookson Ltd., (Northpoint Fourth Way Avonmonth, UK). Hormones and antihormones were dissolved in oily vehicle (Köhle rová and Šk arda, 2004). Heavy-duty Kapak/Scotchpak heat seable pouches were purchased from KAPAK Corporation (Minneapolis, MN, USA).

\section{Animals}

Outbred $\mathrm{C} 3 \mathrm{H}$ mice were from our colony. Animals were maintained on a $12 \mathrm{~h}$ light $/ 12 \mathrm{~h}$ dark lighting schedule (light 06.00-18.00 h), fed pelleted nutritionally complete diet TOP Velas (Lysá n. Labem, Czech Republic). The diet and water were allowed and libitum and the daily routine in the vivarium was constant. To minimize variation of the dose-response relationship of injected hormones, all young animals were weighed at the age of 18 days and only animals weighing $8.5 \pm 1 \mathrm{~g}$ were randomly distributed into the treated groups or used for further breeding.

Young intact (at 18 days of age) and adult gonadectomized (females were ovariectomized at 22-24 days of age, i. e. before the allometric growth phase of the mammary gland; males were castrated at 30-35 days of age) mice were used. Gonadectomy was performed under Avertin anesthesia and administration of compounds begun 15-20 days after operation. Animals were s. c. injected $50 \mu \mathrm{l}$ of oily vehicle (control) or a compound in oily vehicle for 10 or 15 days in females and males respectively. Doses of hormones are expressed in $\mu \mathrm{g}$ per day pro toto. Mean weight of young intact females was $11 \mathrm{~g}$, young intact males $13 \mathrm{~g}$, adult ovariectomized $(\mathrm{OV}-\mathrm{X})$ females $21 \mathrm{~g}$, adult castrated males $24 \mathrm{~g}$. At the end of treatment and within $24 \mathrm{~h}$ of the last hormone administration, animals were weighed and killed. The first pair of inguinal mammary fat pads was removed for whole-mount. Mammary fat pads of males that showed no detectable mammary gland $(10 \%)$ were excluded from the data set, not detectable mammary gland was usually from one side, mammary gland from the other side was used for evaluation. Uteri, spleen and seminal vesicles were dissected out and weighed wet on a precision electronic balance. Spleen weights were not significantly affected by both antiestrogens and antiprogestins and hence were not presented. Weights of uteri and seminal vesicles before expressing the fluid secretion are presented. All experimental procedures were conducted in compliance with the highest standards of humane animal care and approved by the Ethical Committee of the Institute of Animal Physiology and Genetics of the Academy of Sciences. 

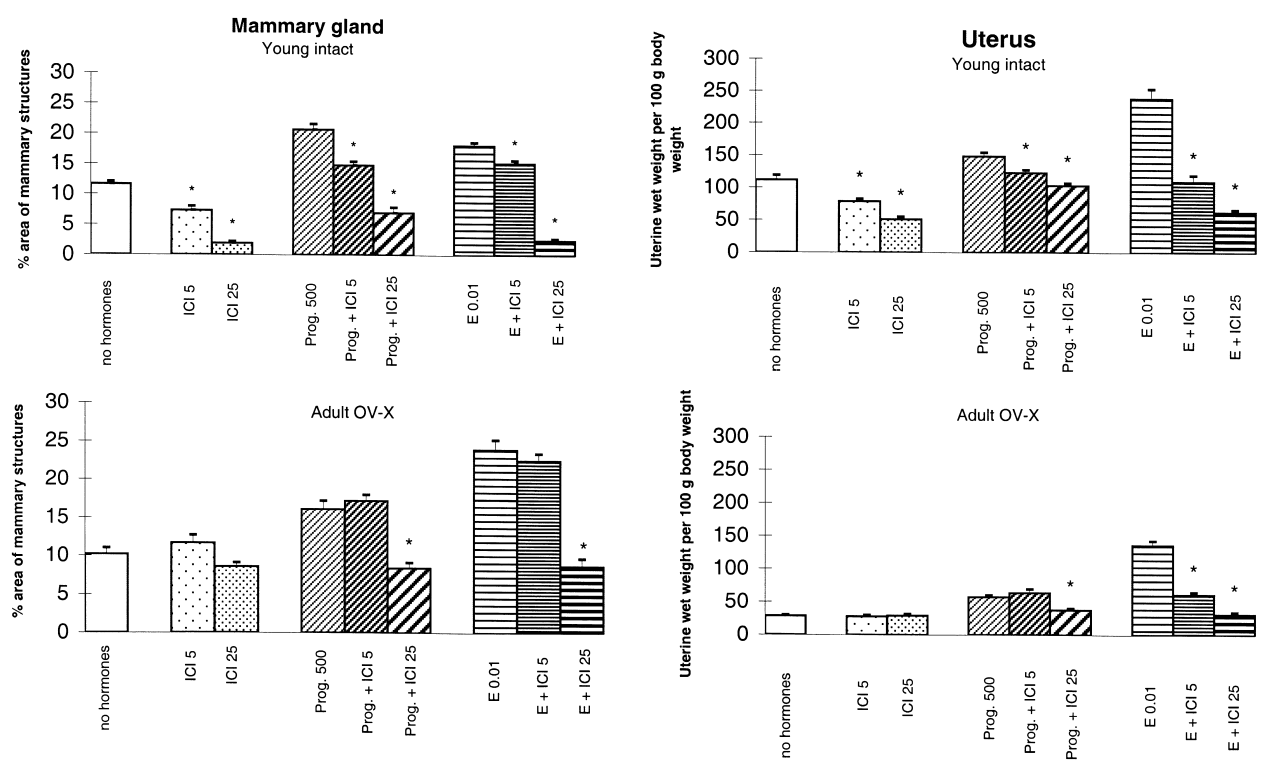

Fig. 1. Effects of ICI 182780 (ICI) alone and in different combinations with progesterone (Prog) and $17 \beta$ estradiol (E) in female mice. Yount intact and adult OV-X (ovariectomized at 22-24 days of age) females (5-21 per group) received subcutaneous injections of vehicle (no hormones) or different daily doses of hormones for 10 days. Values are given as means \pm SEM. Weights of uteri before expressing the fluid secretion are presented.

$* p<0.05$

Mammary whole-mount preparation and quantitative histology

Mammary fat pads were spread as flat as possible, put into Carnovy's fixative and processed as described earlier (Köhlerová and Škarda 2004).

A modification of Chalkley's morphological analysis was used to determine the percentage area of the mammary fat pad occupied by mammary epithelial structures on enlarged $(\times 12)$ photographs of the mammary whole-mount Škarda 2003).

Statistical analysis

All data represent mean \pm SEM. Statistically significant difference was determined by ANOVA, followed by the Bonferroni test for individual comparisons of mean values.

\section{Results}

Young intact and adult OV-X females

To compare the efficacy of ICI and EM, the two compounds were s. c. injected alone or in combination with Prog or E (Fig. 1 and 2). As illustrated in Fig. 1, increasing daily doses ( 5 and $25 \mu \mathrm{g}$ ) ICI alone led to a significant and progressive inhibition of mammary and uterine growth (estrogen antagonist effect) in young intact females. EM, on the other hand, had no significant effect on both mammary and uterine growth.

In adult OV-X females both ICI alone and EM alone had no significant effect on mammary growth. Uterine growth was not affected by ICI alone, whereas it was significantly stimulated (estrogen agonist effect) by EM alone.

In Prog treated young intact and adult OV-X females ICI inhibited both mammary and uterine growth. EM, on the other hand, had no effect on both mammary and uterine growth in young intact females but in adult OV-X females stimulated both mammary and uterine growth (estrogen agonist effect) (Fig. 2).

Both ICI and EM inhibited E (at daily dose $0.01 \mu \mathrm{g}$ ) stimulated mammary and uterine growth in young intact and adult OV-X females. In adult OV-X females treated with high 

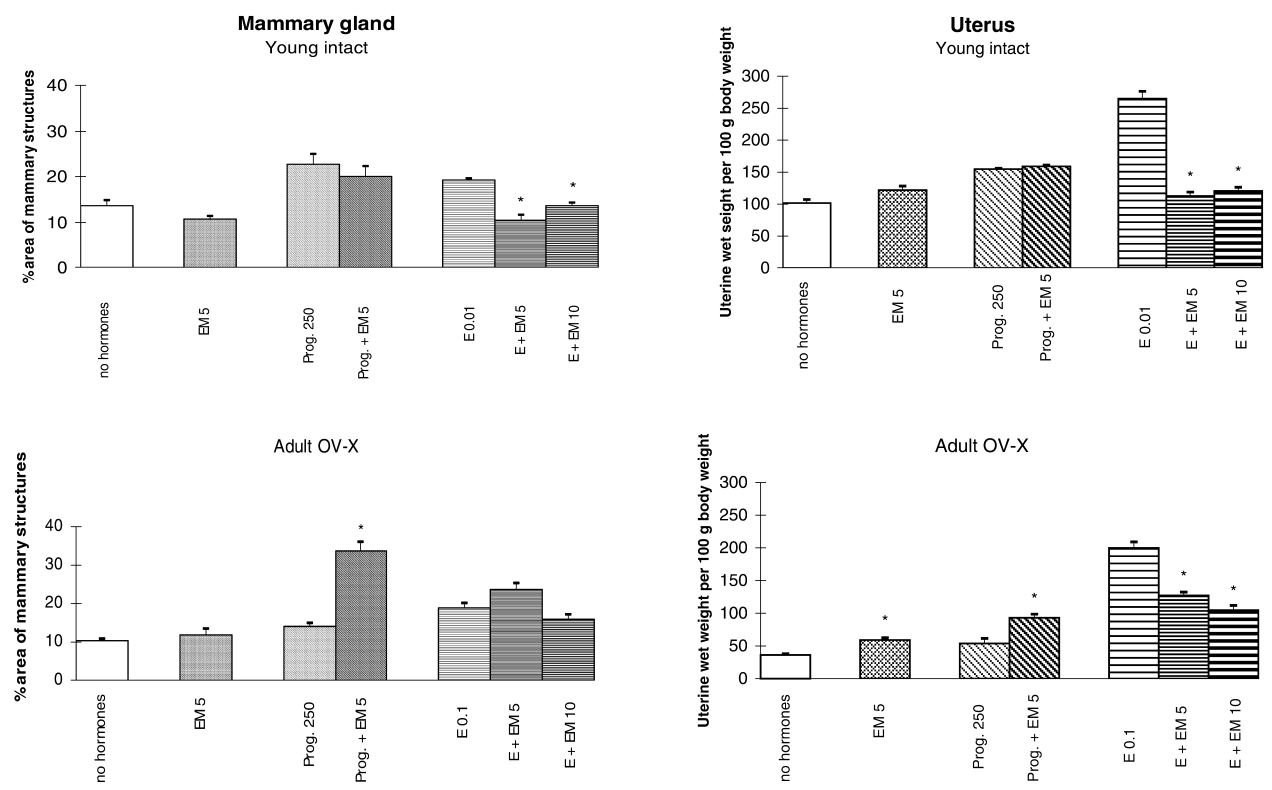

Fig. 2. Effects of EM-800 (EM) alone and in different combinations with Prog and E in female mice. Values are given as means from 4-10 animals \pm SEM. Other details are in the legend to Fig. 1. $* p<005$
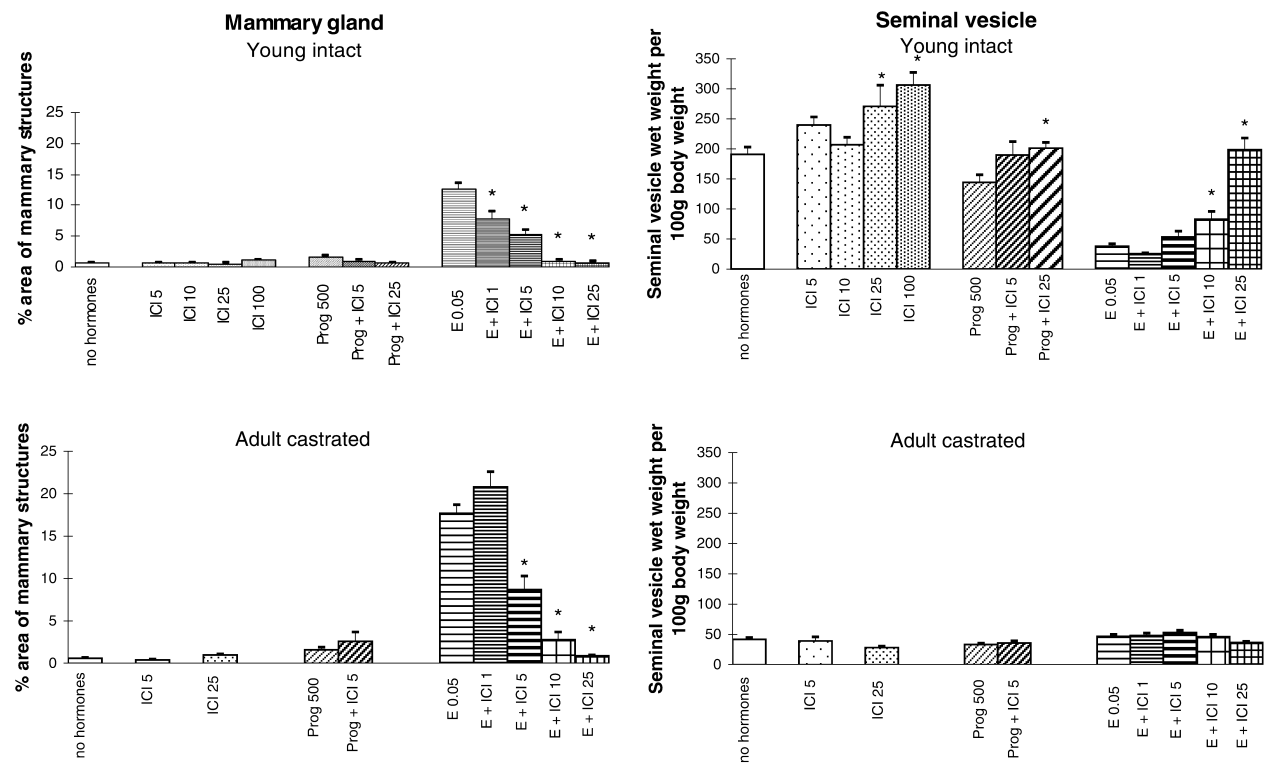

Fig. 3. Effects of ICI 182780 (ICI) alone and in different combination with progesterone (Prog) and $17 \beta$ estradiol (E) in male mice. Young intact and adult castrated males (4-19 per group) received subcutaneous injections of vehicle (no hormones) or different daily doses of hormones for 15 days. Values are given as means \pm SEM. Weights of seminal vesicles before expressing the fluid secretion are presented.

${ }^{*} p<0.05$ 
daily dose $0.1 \mu \mathrm{g}$ of E, mammary growth was not affected by EM at daily doses 5 and $10 \mu \mathrm{g}$, however, uterine weights were decreased by dose-dependent manner.

Young intact and adult castrated males

ICI and EM alone, and ICI or EM plus Prog had no effects on mammary growth in both young intact and adult castrated males (Fig. 3 and 4). The stimulatory effects of E in the mammary glands are efficiently neutralized by coadministration of ICI or EM (an antiestrogenic effect).

Seminal vesicle weights were increased by ICI alone or by a combination of ICI plus Prog or ICI plus $\mathrm{E}$ in prepubertal males (an antiestrogenic effect) but not in adult castrated animals (Fig 3). EM alone had no effect on seminal vesicle weights both in young intact and adult castrated males. In Prog treated young intact males EM increased seminal vesicle weights (an antiestrogenic effect). However, in E treated young intact males EM caused decrease (an estrogenic effect) in seminal vesicle weights. No such stimulatory or inhibitory effects of EM was noted in adult castrated males treated with Prog or E.
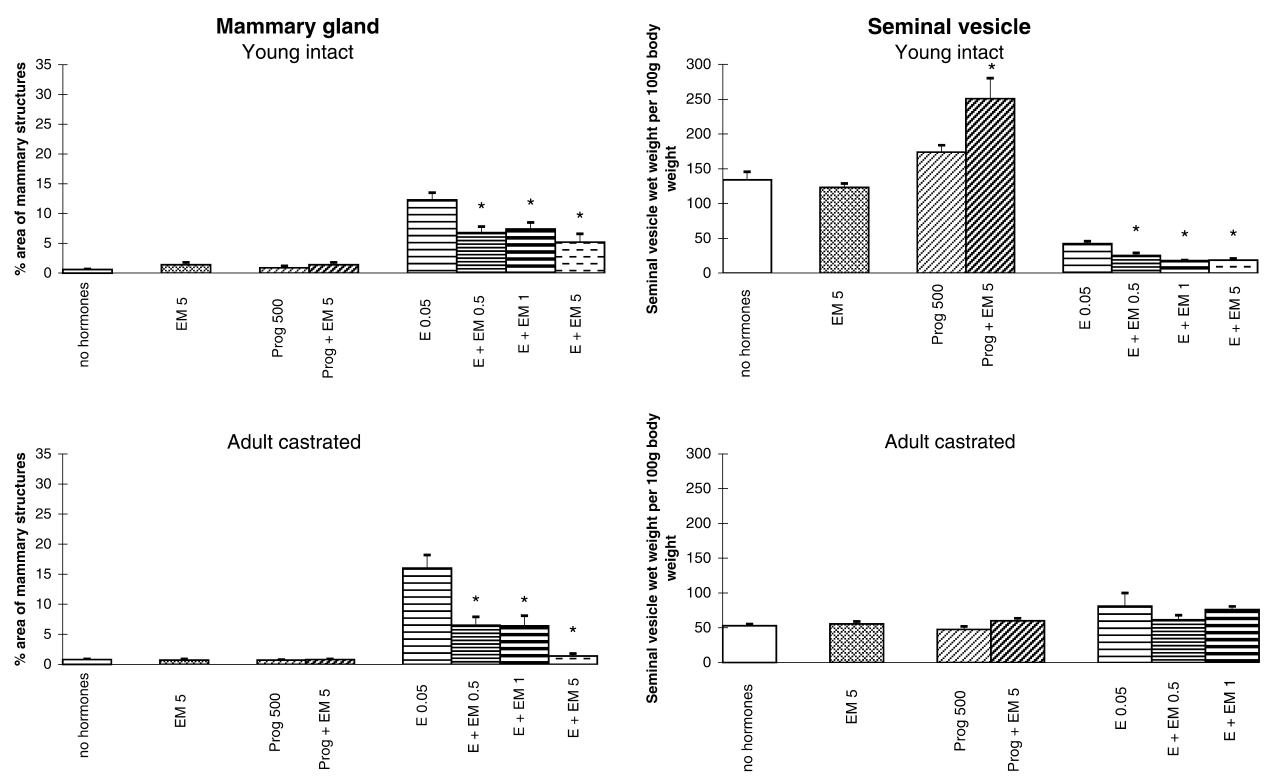

Fig. 4. Effects of EM-800 (EM) alone and in different combinations with Prog and $\mathrm{E}$ in male mice. Values are given as means from 4-8 animals \pm SEM. Other details are in the legend to Fig. 3 .

\section{Discussion}

EM and its active metabolite EM-652 have been shown to exert pure antiestrogenic activity in both human and mouse mammary gland and uterus while being the most potent SERM in the prevention of loss of bone mineral density and as a lowerer of serum cholesterol (Martel et al. 1998; Labrie et al. 1999, 2003). The present data clearly demonstrate that under certain conditions EM possess mixed agonist and antagonist activity also in the mammary gland, uterus and seminal vesicles. EM alone increased uterine weight in adult $\mathrm{OV}-\mathrm{X}$ females and thus, showing an estrogenic activity. The intrinsic estrogenic activity of EM was also demonstrated in the mammary gland and uterus of Prog treated adult OV$\mathrm{X}$ females and in seminal vesicles of $\mathrm{E}$ treated young intact males. Contrary to EM, ICI always decreased mammary growth, uterine weight and increased seminal vesicle growth 
under similar conditions, thus showing no intrinsic estrogenic activity in mice similarly as it was demonstrated in rats, pigs, monkey and woman (Wakeling et al. 1991; Dukes et al 1993; Branham et al. 1996; Thomas et al 1996; Tarleton et al. 1999). However, in sheep ICI acts like E agonist by increasing redness and endometrial weights and oxytocin and prostaglandin F2 $\alpha$ secretion (All-Matubsi et al. 1998; Robertson et al. 2001). These facts clearly indicate a true species difference of sheep with rodents, pig, monkey and human species. On the other hand, 4-OH-tamoxifen, an antiestrogen widely used for the treatment of breast cancer in women (Macgregor and Jordan, 1998), behaves in the mouse uterus as relatively potent estrogen both when injected alone and in combination with E, Prog or E plus Prog (Köhlerová and Škarda 2004).

EM decreased mammary and uterine growth in young intact females treated with low daily dose of $\mathrm{E}(0,1 \mu \mathrm{g})$. EM was able to inhibit uterine growth but not mammary growth in adult OV-X females. These results demonstrate that antiestrogenic activities of EM in the mammary gland could be seen only in animals treated with submaximal doses of E. Extremely high doses of E overload the organism, so that antiestrogens do not have the ability to compete with $\mathrm{E}$ for ER and to decrease mammary growth.

In young intact, but not in adult castrated males, ICI increased seminal vesicle growth affected by both endogenous and exogenous (Prog or E) hormones and EM increased growth of seminal vesicles in Prog treated prepubertal males. Thus, the antiestrogenic effect of ICI and EM on seminal vesicles is dependent on the presence of testes and could be related to inhibition of both estrogen synthesis in the Sertoli, Leydig and germ cells of testes (Hess et al. 2001) and estrogen action in seminal vesicles. On the other hand, EM synergized with E in decreasing seminal vesicle weights and thus showing estrogenic activity.

In conclusion pure steroidal antiestrogen ICI, decreased mammary and uterine growth stimulated by endogenous hormones in young intact females and by exogenous hormones (Prog or E) in both young intact and adult OV-X females. Nonsteroidal antiestrogen EM, on the other hand, had no effect on mammary and uterine growth stimulated by endogenous hormones in young intact females and in mammary gland of adult OV-X females. However, uterine growth in adult OV-X females was stimulated by EM alone and a combination of EM plus Prog stimulated not only uterine growth but also mammary growth, thus showing estrogenic agonist activities. EM showed antiestrogenic activities in the mammary gland of young intact females and in uterus of both young intact and adult OV-X females treated with E. In males, ICI and EM decreased mammary growth stimulated by exogenous $\mathrm{E}$ in both young intact and adult castrated animals. ICI also showed an antiestrogenic activity in seminal vesicles of both E or Prog treated young intact males. However, EM showed both antiestrogenic activity in seminal vesicles of Prog treated animals and an estrogenic activity in E treated animals.

\section{Rozdílné schopnosti steroidního (ICI 182 780) a nesteroidního (EM-800) antiestrogenu inhibovat růst reprodukčních orgánů samců a samic myší.}

Změny v růstu mléčné žlázy, dělohy a semenných váčků byly použity k identifikaci aktivit antagonistů estrogenů $\mathrm{v}$ podmínkách in vivo. Na čtyřech modelech ( mladé intaktní a dospělé gonadektomované samice a samci myší) byly testovány účinky samotných antagonistů a kombinací antagonistů s estradiolem (E) nebo progesteronem (Prog). ICI 182 780 (ICI) se vždy choval jako antiestrogen: růst mléčné žlázy intaktních prepubertálních a dospělých ovariektomovaných (OV-X) samic snížil ICI jak samotný, tak v kombinaci $\mathrm{s}$ E nebo Prog. Podobně ICI snižil E stimulovaný růst mléčné žlázy intaktních prepubertálních a dospělých kastrovaných samců. Samotný ICI snížil růst dělohy $\mathrm{u}$ prepubertálních samic a ICI $\mathrm{v}$ kombinaci s Prog nebo $\mathrm{E}$ snížil růst dělohy jak u prepubertálních, tak u dospělých OV-X samic. Hmotnost semenných váčkủ mladých 
prepubertálních samců ICI zvýšil a to jak samotný, tak v kombinaci s E nebo Prog. Naproti tomu samotný EM-800 (EM) neměl žádný účinek na růst mléčné žlázy i dělohy prepubertálních samic, zatímco u dospělých OV-X samic samotný EM růst dělohy stimuloval a v kombinaci s Prog stimuloval nejen růst dělohy, ale i mléčné žlázy. Růst semenných váčků je u E ošetřených prepubertálních samců EM snížen (estrogenní účinky). E stimulovaný růst mléčné žlázy prepubertálních i dospělých gonadektomovaných samic a samců však EM snížil a podobně EM snížil i E stimulovaný růst dělohy prepubertálních a dospělých OV-X samic a naopak EM zvýšil růst semenných váčků u Prog ošetřených prepubertálních samců (antiestrogenní účinky).

\section{Acknowledgements}

We are grateful to Eva Urbanová for excellent technical assistance, Dr. A. E. Wakeling (Zeneca Pharmaceuticals, Macclesfield, England) for gift of ICI 182780 and to Professor F. Labrie (Oncology and Molecular Endocrinology Research Center, Laval Univ. Med. Center, Québec, Canada) for gift of EM-800. This work was funded by the Grant Agency of the Academy of Sciences of the Czech Republic (Grant No-IBS 5045302) and Institutional Resesarch Plan IAPG (No. AV0Z50450515)

\section{References}

ALL-MATUBSI H, FAIRCLOUGH RJ, JENKIN G 1998: Oestrogenic effects of ICI 182, 780, a putative antioestrogen on the secretion of oxytocin and prostaglandin F $2 \alpha$ during oestrus cycle in the intact ewe. Anim Prod Sci 51: $81-96$

BARKHEM T, CARLSSON B, NILSSON Y, ENMARK E, GUSTAFSSON J-A, NILSSON S 1998: Differential response of estrogen alpha and estrogen receptor beta to partial estrogen agonists/antagonists. Mol Pharmacol 54: $105-112$

BEATO M, HERZLICH P, SCHÜTZ G 1995: Steroid hormone receptors: many actors in Search of a plot. CELL 83: $851-857$

BRANHAM WS, FISHMAN R, STRECK RD, MEDLOCK KL, DEGEORGE JJ, SHEEHAN DM 1996: ICI 182, 720 inhibits endogenous estrogen-dependent rat uterine growth and tamoxifen-induced developmental toxicity. Biol Reprod 54: 160-167

COWLEY SM, HOARE S, MOSSELMAN S, PARKER MG 1997: Estrogen receptors alpha and beta form heterodimers on DNA. J Biol Chem 272: 19858-19862

DUKES M, WATERTON JC, WAKELING AE 1993: Antiuterotrophic effects of the pure antiestrogen ICI 182, 780 in adult female monkey (Macaca nemestrina): quantitative magnetic resonance imaging. J Endocrinol 138: 203-209

ENMARK E, PELTO-HUIKKO M, GRANDIEN K, LAGERCRANTZ S, LAGERCRANTZ J, FRIED G, NORDEMSKJOLD M, GUSTAFSSON J-A 1997: Human estrogen receptor beta-gene structure, chromosomal localization, and expression pattern. J Clin Endocrinol Metab 82: 4258-4265

HESS RA, BUNICK D, BAHR J 2001: Oestrogen, its receptors and function in the male reproductive tracta review. Mol Cell Endocrinol 178: 29-38

HOFFMANN B, SCHULER G 2000: Receptor blockers-general aspects with respect to their use in domestic animal reproduction. Anim Reprod Sci 60-61: 295-312

HUFRIY A, KÖHLEROVÁ E, SKARDA J 2003: Morphometric criteria for bioassay of agonist and antagonist actions of steroid hormones on the mammary gland. Acta Vet Brno 72: 483-491

JACOBS AL, EDGERTON LA, SILVIA WJ, SCHILLO KK 1988: Effect of an estrogen antagonist (tamoxifen) on cloprostenol-induced luteolysis in heifers. J Anim Sci 66: 735-742

JANOWSKI T, ZDUNCZYK S, PODHALICZ-DZIEGIELEWSKA M, RASZ A, CHMIELEWSKI A 1996: Effect of oestrogen antagonist (tamoxifen) on steroid hormone levels, maturation process of placentomes and course of late pregnancy in cows. Reprod Domest Anim 31: 379-384

KUIPER G-G, ENMARK E, PELTO-HUIKKO M, NILSSON S, GUSTAFSSON J-A 1996: Cloning of a novel receptor expressed in rat prostate and ovary. Proc Natl Acad Sci U.S.A. 93: 5925-5930

KUIPER G-G, CARLSSON B, GRANDIEN K, ENMARK E, HAGGBLAD J, NILSSON S, GUSTAFSSON JA 1997: Comparison of the ligand binding specificity and transcript tissue distribution of estrogen receptor alpha and beta. Endocrinology 138: 863-870

KÖHLEROVÁ E, ŠKARDA J 2004: Mouse bioassay to assess oestrogenic and antioestrogenic compounds: hydroxytamoxifen, diethylstilbestrol and genistein. J Vet Med A 51: 209-217

LABRIE F, LABRIE C, BÉLANGER A, SIMARD J, GAUTHIER S, LUU-THE V, MÉRAND Y, GIGUERE V, CANDAS B, LUO S, MARTEL C, SINGH SM, FOURNIER M, COQUET A, RICHARD V, CHARBONNEAU R, CHARPENET G, TREMBLAY A, TREMBLAY G, CUSAN L, VEILLEUX R 1999: EM-652 (SCH 57068), a third generation SERM acting as pure antiestrogen in the mammary gland and endometrium. J Steroid Biochem Mol Biol 69: 51-84 
LABRIE F, ELL-ALFY M, BERBER L, LABRIE C, BÉLANGER A, CANDAS B, PELLETIER G 2003: The combination of novel selective estrogen receptor modulator with an estrogen protects the mammary gland and uterus in a rodent model: the future of postmenopausal women's health? Endocrinology 144: 4700-4706

MACGREGOR JI, JORDAN NC 1998: Basic guide to the mechanism of antiestrogen action. Pharmacol Rev 50: 151-196

MARTEL C, LABRIE C, BÉLANGER A, GAUTHIER S, MÉRAND Y, LI X, PROVENCHER L, CANDAS B, LABRIE F 1998: Comparison of the effects of the newly orally active antiestrogen EM-800 with ICI 182780 and toremifene on estrogen-sensitive parameters in the ovariectomized mouse. Endocrinology 139: 2486-2492

NILSSON S, KRUIPER G, GUSTAFSSON J-A 1998: ER $\beta$ : a novel estrogen receptor offers the potential for new drug development. Trends Endoc Metab 9: 387-395

PAIGE LA, CHRISTENSEN DJ, GRON H, NORRIS JD, GOTTLIN EB, PADILLA KM, CHANG C-Y, BALLAS LM, HAMILTON PT, MCDONELL P 1999: Estrogen receptor (ER) modulators each induce distinct conformational changes in Ero and Erß. Proc Natl Acad Sci USA 96: 3999-4004

PAYNE J, RAJAPAKSE N, WILKINS M, KORTENKAMP A 2000: Prediction and assessment of the effects of mixtures of four xenoestrogens. Environ Health Perspec. 108: 983-987

ROBERTSON JA, ZHANG Y, ING NH 2001: ICI 182, 780 acts as a partial agonist and antagonist of oestradiol effects in specific cells of the sheep uterus. J Steroid Biochem Mol Biol 77: 281-287

SHARPE RM 1998: The roles of oestrogen in the male. Trends Endocrinol Metab 9: 371-377

ŠKARDA J 2001: Detection of estrogenicity by bioassay on the mouse mammary gland in vivo. Physiol Res. 50: 275-282

ŠKARDA J 2002a: Sensitivity and specificity of the bioassay of estrogenicity in mammary gland and seminal vesicles of male mice. Physiol Res 51: 267-276

ŠKARDA J 2002b: Sensitivity and specificity of bioassay of estrogenicity on mammary gland and uterus of female mice. Physiol Res 51: 407-412

ŠKARDA J 2002c: Norethindrone acetate and testosterone interaction in mammary gland, uterus and seminal vesicles of mice. Acta Vet Brno 71: 463-471

ŠKARDA J 2003: Bioassay of steroid hormone agonist and antagonist activities of anti-androgens on mammary gland, seminal vesicles and spleen of male mice. J Vet Med A 50: 204-212

TARLETON BJ, WILEY AA, BARTOL FF 1999: Endometrial development and adenogenesis in the neonatal pig: effects of estradiol valerate and the antiestrogen ICI 182, 780. Biol Reprod 61: 253-263

TENA-SEMPERE M, NAVARRO J, PINILLA L, GONZÁLEZ LC, HUHTANIEMI I, AGUILAR E 2000: Neonatal exposure to estrogen differentially alters estrogen receptor $\alpha$ and $\beta$ mRNA expression in rat testis during postnatal development. J Endocr 165: 345-357

THOMAS EJ, WALTON PL, THOMAS NM, DOWSETT M 1996: The effect of ICI 182, 780, a pure antioestrogen, on the hypothalamic-pituitary-gonadal axis and on endometrial proliferation in premenopausal women. HUM REPROD 9: 1991-1996

WAKELING AE, DUKES M, BOWLER J 1991: A potent specific pure antiestrogen with clinical potential. Cancer Res 51: 3867-3873 
